\title{
Using part-time working to support graduate employment
}

\section{Needs and perceptions of employers}

\author{
Carl Evans, Tim Maxfield and Gbolahan Gbadamosi
}

\begin{abstract}
An exploration of the value attached to the work experience of graduates, and particularly the value of part-time working whilst studying for a degree, from an employer's perspective, is reported. A documentary analysis of graduate recruiters was conducted to assess the extent to which work experience was specified for graduate employment programmes. Further interviews were then carried out with a sample of small and medium-sized enterprises (SMEs) to explore how the part-time working of graduates is perceived by employers. Work experience is deemed to be important to employers, not only as a differentiator but also as a measure of how graduates will perform in-post. Employers generally signalled the value of work experience, but indicated that graduates did not make best use of it in their job applications. It is argued that the findings will provide information to universities and educators about the contribution and importance of students' part-time working in terms of graduate employment prospects and with respect to the employability agenda in the HE curriculum in the UK.
\end{abstract}

Keywords: employability; employers; graduate careers; part-time working

Carl Evans (corresponding author) is with the Faculty of Sport, Media and Creative Arts, University of St Mark \& St John, Derriford Road, Plymouth PL6 8BH, UK. E-mail: cevans@marjon.ac.uk. Tim Maxfield is with the Business School, University of Worcester, Worcester WR1 3AS, UK. E-mail: t.maxfield@worc.ac.uk. Gbolahan Gbadamosi is with the Business School, University of Bournemouth, 89 Holdenhurst Road, Bournemouth BH8 8EB, UK. E-mail: ggbadamosi@bournemouth.ac.uk.

The employability of graduates remains high on the UK government's agenda (Tomlinson, 2007), with universities increasingly seeking to support students' transition into graduate employment. However, the process by which students move seamlessly from higher education into the workplace is far from straightforward, despite the relatively simple definition of 'employability' - for example, 'The character or quality of being employable' (McQuaid and Lindsay,
2003, p 199). Similarly, Pan and Lee (2011) use employability to describe the skills and attributes possessed by individuals which make the students attractive to employers, or as Shafie and Nayan (2010) refer, getting them to be in a state of 'job-readiness'. However, employability is not merely the process of endowing individuals with appropriate knowledge and skills; equally important is the development of personal attributes to facilitate entry to and advancement along a 
JOBNAME: IHE PAGE: 2 SESS: 4 OUTPUT: Wed Jul 15 13:24:49 2015

/hling/journals/ipp/105/484638

Using part-time working to support graduate employment: employer needs and perceptions

graduate career path (Harvey, 2005; Knight and Yorke, 2002). This has led to demands that universities embed employability skills in the learner experiences (Rae, 2007; Støren and Aamodt, 2010), or involve employers in curriculum design (Mason et al, 2009). Employability skills are, however, not universal (Pan and Lee, 2011) and questions about whether students themselves are capable of acquiring them have been raised (Tymon, 2011). As Rae (2007) highlights, a broad approach to graduate employability is made difficult by individual characteristics, personality and personal motivations, all of which can be shaped by university experiences.

As a consequence, the relationship between universities, students and employers remains complex, with work experience activities deemed to be 'extra-curricular' (Harvey, 2005), rather than an integral part of the degree programme (Knight and Yorke, 2002). The debate continues, therefore, as to whether higher education institutions (HEIs) are producing graduates who are 'industry-ready' (Boden and Nedeva, 2010; Wilton, 2008). Employers themselves are becoming increasingly explicit in their requirement for graduates not only to possess requisite skills, such as problem-solving or effective communication (Wilton, 2008), but also to be able to make an effective contribution to the business from the outset of engagement (CMI, 2014). It is the ability of graduates to have an immediate effect on business performance that differentiates the skills needs of small and medium-sized enterprises (SMEs) from those of large organizations (Stewart and Knowles, 2000a). Given their limited resources, it is unsurprising that SMEs need to maximize the benefits derived from workforce investments. Nonetheless, Stewart and Knowles (2000b) did find commonality between the skills needs of large businesses and SMEs, particularly regarding transferable skills. Despite a need for skilled labour to support innovation and growth, however (OECD, 2013), SMEs experience difficulty in attracting graduates (UEAPME, 2011). In the UK, the Department for Business, Innovation and Skills (BIS, 2012) has confirmed that graduates tend not to be targeted for positions in SMEs, due predominantly to a lack of financial resources causing the SMEs to be unable to accommodate graduate expectations regarding pay (Heaton et al, 2008). There is also the possibility of SMEs being unable to attract graduates because of a lack of structured training and development (Hunt et al, 2011). However, Sfedi (2012) also cite a lack of work and lack of practical experience of graduates as reasons for graduates not to be targeted as candidates for vacancies. This has caused Stewart and Knowles (2000a) and Branine (2008) to look to universities to provide a better 'fit' between graduates and SMEs.
However, as Yorke (2004) noted, achievements other than the formal degree are deemed important by employers. This is confirmed by Tomlinson (2007) who noted that degree students felt that a degree alone was insufficient in the (then) current graduate jobs market, a perception that persists to the present time (that is, 2015).

Individuals choose to go to university for a number of reasons, but typically it is either to gain access to a profession such as medicine (for which undergraduate studies and a graduate degree remain essential), or because a degree is perceived as delivering net financial benefits during the course of an individual's working life (Ryan, 2010). However, the lack of 'guaranteed employment' for graduates, coupled - in England, in particular - with increased tuition fees, perhaps mean that individuals are now examining the alternatives to full-time university studies. This has also led to the development of new initiatives, such as the 'School Leaver Programme' (http://www.allaboutschool leavers.co.uk/jobs), and apprenticeship schemes at various levels including advanced and higher apprenticeships. Apprenticeships, embracing an 'earn while you learn' approach and covering a broad spectrum of career options (http://www.ucas.com) provide a clear challenge to the traditional university-degree route. Moreover, apprenticeships seem to be well received by employers, ranking higher than first degrees in terms of perceived 'employability' (ICM, 2013). However, while the media has highlighted the superiority of apprenticeships over a degree (for example, Collins, 2013), research among working parents has indicated the opposite (CIPD, 2013).This has served to revive discussion on the need for individuals to possess appropriate workplace skills, particularly to support the growth of SMEs (Cherry, 2015). HEIs have responded to the need for a greater vocational emphasis in degree programmes, with an increased focus on work-based learning initiatives (Burke et al, 2009; Hills et al, 2003) in order to develop those skills demanded by employers (Burn-Callander, 2014). This need for engaging with the workplace is confirmed by High Fliers (2014) in their Graduate Market Report, who warn that graduates with no work experience are unlikely to secure employment on a graduate programme with over half of the top-100 graduate employers in the UK. However, the work experience referred to here focuses largely on those employers' own placement and internship programmes, with suggestions that a number of graduate positions are reserved for those who had previously undertaken internships at the company concerned (Paton, 2014; Vasagar, 2011). Nonetheless, Paisley and Paisley (2010) and Juznic and Pymn (2011) 
are positive about work placements enhancing skills that might be transferred to the workplace, although students find relating work placement activities to the programme of study something of a challenge (Smith et $a l, 2007)$. In addition, some concerns have been raised about too many students undertaking work placements (Harrison, 2004), potentially restricting appropriate skill development. Consequently, the role of work-based learning has been given greater prominence by HEIs because it not only seeks to maximize learning in the workplace (Burke et al, 2009), but also provides a ready conduit into employment (Hills et al, 2003). Equally, internships can provide work experience with a desired organization (Cummings-Carson, 2013; Helyer and Lee, 2014). This is why work placement, work experience and internships have become commonplace - they readily provide an individual with an opportunity to gain first-hand experience in order to develop and hone skills acquired at university, although there has been some adverse media coverage regarding the ethical stance of some internship opportunities (Ellis, 2014).

Nonetheless, the focus has been on placements and internships and as a result another significant source of work experience for students, that of part-time working while studying for the degree, has been largely ignored. While universities are developing a host of initiatives for students to undertake work experience, a significant proportion of undergraduate students are undertaking part-time work (NUS, 2009, 2010; UCAS, 2011) on their own initiative. While this is mostly seen to be financially driven (Richardson et al, 2009), part-time working can also help individuals 'try-out' future jobs (Billet and Ovens, 2007) and is therefore useful in supporting career aspirations. In addition, the students themselves perceive their part-time working as beneficial to their job prospects (Evans et al, 2014; Martin and McCabe, 2007; Morrison, 2009). However, the value placed by employers on students' part-time working remains relatively unexplored.

\section{Research questions, rationale and objectives for this study}

This study is prompted by the work of Wilton (2011), who suggested that research among employers on the value of particular skills and experience they seek would help identify key factors in graduate recruitment. This leads to the first objective for this study:

Objective 1: To assess the extent to which employers specify work experience for their graduate employment programmes.
However, a number of questions remain unanswered with regard, to the value of part-time work in supporting graduate employability, as introduced above, highlighting a clear 'research-gap'. In particular, the following questions arise.

- To what extent is part-time work seen to add-value to an individual's application for graduate positions?

- Are some part-time work activities deemed by employers to be more useful than others?

- Does part-time work help differentiate individuals in the graduate jobs market?

- How can students use their part-time work experience more effectively to enhance graduate employability prospects?

Given that this is an exploratory study, these questions provide impetus for the second objective of this research:

Objective 2: To explore how part-time working is perceived by employers, particularly how it supports graduate job applications.

\section{Research approach}

\section{Documentary analysis}

The research approach is split into two elements in order to achieve the two objectives. The first part is a documentary analysis (Krippendorff, 2013) of the graduate recruitment sections of organizations' websites, to assess the extent to which work experience was a stated entry requirement to a graduate position. As Bennett (2002) noted, employers are typically explicit in job advertisements regarding the skills demanded for particular positions. In addition, Feldman et al (2006) considered the importance of job advertisements in signalling key points to prospective applicants and thus acting as the 'bridge' between the employer and prospective applicant (Mathews and Redman, 1998).

A sample group of organizations to be examined was derived from the publications The Times Top 100 Graduate Employers, and the Job Crowd Top Companies for Graduates to Work For (2013-2014). ${ }^{1}$ By eliminating those companies duplicated in the second publication, this yielded a sample of $(100+$ $113)=213$ organizations. These publications were deemed appropriate as the source of a sample because they were deemed those most likely to be read by students seeking graduate positions upon graduation, at least as a starting point in their search for employment.

The graduate recruitment sections of the 213 organizations' websites and linked brochures/publicity 
JOBNAME: IHE PAGE: 4 SESS: 4 OUTPUT: Wed Jul 15 13:24:49 2015

/hling/journals/ipp/105/484638

Using part-time working to support graduate employment: employer needs and perceptions

material were analysed to determine the extent to which work experience was a stated requirement for graduate positions. The work experience stated in the organizations' documents was noted, with each business graded into one of the following coding units (Wienslaw, 2009):

(1) Explicitly stated that work experience was essential/mandatory;

(2) Explicitly stated that work experience was desirable;

(3) Implied that work experience was useful (in order to demonstrate a skill or behaviour);

(4) No mention of work experience;

(5) Work experience was explicitly stated as not required; and

(6) Explicitly stated that previous work experience was undesirable or limited (e.g. maximum 12 months).

While it is accepted that there is some degree of interpretation in a qualitative content analysis (Schreier, 2012), the above units summarized the extent of stated work experience described in the documents. Because a broad measure of stated work experience was sufficient for this study, a sophisticated content analysis was regarded as unnecessary - for example, to take account of synonyms or grammatical variations. A simple 'counting' method (Krippendorff, 2013, p 189) was therefore adopted. An approach similar to that adopted by Wellman (2010) in his analysis of marketing jobs was used, entering the item counts into a spreadsheet, to enable tabular or graphical data presentation.

\section{Interviews with SME managers}

Because the second research objective dealt with exploring how part-time working is perceived by employers, and in particular how part-time working supports graduate job applications, it was felt that an interview-based approach (Gray, 2014) would provide greater insight than one based on a survey. The study was therefore qualitative descriptive (Sandelowski, 2010). Moreover, this element also enabled the perceptions of SMEs to be sought, rather than those of larger organizations typically associated with the documentary analysis. These interviews complemented the documentary analysis, enhancing data quality.

Recruitment managers at nine graduate recruiters, with offices located in the West Midlands, UK, were interviewed to explore the importance they attach to work experience, and especially that derived from part-time jobs. These businesses were selected because they did not appear in the publications used for the documentary analysis. In addition, one of the authors had previous working experience with businesses - for example through joint university and Chamber of Commerce events - or they had taken students on work
Table 1. Details of companies.

\begin{tabular}{ll}
\hline Company reference & Type of company \\
A & Accountants \\
B & Bank \\
C & Accountants \\
D & IT software developer \\
E & High-tech manufacturer \\
F & Housing association \\
G & Solicitors \\
H & Housing association \\
I & Manufacturer \\
\hline
\end{tabular}

placement and were known to have recruited graduates in the previous year. The sample could therefore be termed convenience. The businesses were not identified according to a single particular industrial sector, and thus organizations from the financial services, housing, manufacturing and IT sectors formed part of the sample group (see Table 1).

Given that the purpose of this element of the study was to explore in greater depth the perceptions of employers in respect of part-time work of students, it was felt that each individual business would offer a useful contrasting qualitative perspective to that of the documentary analysis, particularly from an SME standpoint. Ethical approval, as a mandatory requirement for academic research using human participants, was granted by the university. The interviews were completely anonymous and respondents were informed they could withdraw at any time if they did not want to proceed. The interviews were conducted at the offices of each of the respective businesses by one of the researchers, to ensure a consistent approach in the data gathering process.

Each interview was based upon 16 questions, with introductory questions relating to graduate recruitment and selection methods and then more specific questions to explore perceptions relating to part-time working. The responses were not audio recorded, but shorthand notes were taken which were then word-processed in full. Participants were subsequently requested to confirm the transcription and thus ensure correct representation of their views. The interviews were subsequently content analysed for commonality within the responses, identifying common themes which were tabulated. The companies have been allocated a letter (see Table 1) in order to identify their comments in the text, but to maintain anonymity.

\section{Findings}

Documentary analysis

The documentary analysis revealed the importance employers attach to work experience. For $11.3 \%$ of 
JOBNAME: IHE PAGE: 5 SESS: 4 OUTPUT: Wed Jul 15 13:24:49 2015

/hling/journals/ipp/105/484638

Using part-time working to support graduate employment: employer needs and perceptions

\begin{tabular}{|c|c|c|}
\hline \multicolumn{3}{|c|}{$\begin{array}{l}\text { Table 2. Classification of businesses by stated work } \\
\text { experience requirements. }\end{array}$} \\
\hline Grade & Work experience requirements & $\begin{array}{l}\text { Number of } \\
\text { businesses } \\
\text { (\%) }\end{array}$ \\
\hline 1 & $\begin{array}{l}\text { Explicitly stated that work experience } \\
\text { was essential/mandatory. }\end{array}$ & $24(11.3 \%)$ \\
\hline 2 & $\begin{array}{l}\text { Explicitly stated that work experience } \\
\text { was desirable. }\end{array}$ & $20(9.4 \%)$ \\
\hline 3 & $\begin{array}{l}\text { Implied that work experience was } \\
\text { useful (to demonstrate a skill or } \\
\text { behaviour). }\end{array}$ & $43(20.2 \%)$ \\
\hline 4 & No mention of work experience. & $120(56.3 \%)$ \\
\hline 5 & $\begin{array}{l}\text { Explicitly stated that work experience } \\
\text { was not required. }\end{array}$ & $5(2.3 \%)$ \\
\hline \multirow[t]{2}{*}{6} & $\begin{array}{l}\text { Explicitly stated that previous work } \\
\text { experience was undesirable or limited } \\
\text { (for example, maximum } 12 \text { months). }\end{array}$ & $1(0.5 \%)$ \\
\hline & Total & $213(100 \%)$ \\
\hline
\end{tabular}

graduate recruiters, work experience was mandatory (Table 2), with some specifying minimum periods of work, while others specified that the experience had to be relevant to the company's industrial sector (e.g. retail), clearly highlighting the importance of internships.

What also emerged for businesses in this category was the need for students to be able to cite examples from their work experience and relate this to the company or position for which they were applying. Students are therefore required to articulate the skills they developed in work situations, and express how these might now be valuable to the prospective employer. This also extended into those $9.4 \%$ of businesses classified as '2' (Table 2). Without explicitly specifying that graduates must have work experience, employers in this category are seemingly looking for evidence of how individuals can demonstrate transferable skills, by asking for details of any work experience. Relevant work experience can therefore be invaluable for an individual, to draw on for examples of how transferable skills have be developed or applied in practice. These were also apparent for the $20.2 \%$ of businesses in category ' 3 ', where applicants might be required, for example, to demonstrate their interest in the company/sector or their passion for customer service, both of which could be effectively supported by appropriate examples of work experience.

Even though the $56.3 \%$ of companies graded as ' 4 ' did not explicitly require work experience, $72 \%$ within this group typically specified expected behaviours or
Table 3. Breakdown of the 120 companies graded as 4 (no mention of work experience) in Table 2.

\begin{tabular}{lc} 
Grade 4 & $\begin{array}{l}\text { Number of } \\
\text { businesses (\%) }\end{array}$ \\
No details & $27(22 \%)$ \\
Apply for specific jobs & $6(5 \%)$ \\
No graduate scheme & $1(1 \%)$ \\
Listed desirable behaviours/traits & $86(72 \%)$ \\
Total & $120(100 \%)$ \\
\hline
\end{tabular}

traits to be demonstrated by the applicant. This might include communication skills, leadership capabilities, social skills, and so on, which could be acquired from work experience (see Table 3 ).

Only $2.3 \%$ of companies stated explicitly that work experience was not required for their graduate recruitment programme (Table 2). However, these organizations would not only be looking for high-level academic achievement but also investigating why an individual has an interest in that particular business or sector. This is something that individuals with work experience, particularly related internships, will be able to explain more effectively. These organizations will undoubtedly have structured graduate schemes that develop and mould individuals from a zero knowledge-base for the particular business or sector. Similarly, the single business that specified a maximum period work experience in category ' 6 ' will presumably have a structured graduate scheme with a related pay-scale.

\section{Interviews}

While not expressly stated as mandatory, the importance of graduates possessing work experience was clearly reinforced by the employers interviewed. Previous work experience is regarded by employers as a differentiator for selecting between two similar applicants:

'PT work experience allows differentiation between two individuals with similar academic profiles. The candidate with PT work experience will know what it is like to go to work.' (Company I)

'If we had a choice between two candidates, one a graduate with no work experience and the other who had work experience, then we would probably favour the candidate with work experience.' (Company A)

Previous work experience is also perceived by employers to equip individuals with a broader range of skills and experiences and help develop skills that are readily transferable to the workplace: 
'We want people who can socialise and interact. Wouldn't pick the person with the First Class Honours degree if they could not demonstrate these skills.' (Company B)

'Work experience is "'all good'. At least those with it can demonstrate the importance of customer facing skills and so on. Real life skills are very important.' (Company A)

In addition to the essential transferable skills, businesses are looking for individuals who can adapt more readily to the world of work, and part-time work experience is seen to provide applicants with this ability:

'In all positions, part time work experience is advantageous. This makes a candidate look better. They may have picked up transferable skills, and it softens the teething problems there may be otherwise.' (Company D)

'We are looking for past experience as a predictor of how they are going to work.' (Company I)

In particular, the ability to engage appropriately with customers confirmed the previously noted documentary findings:

'People who have part-time work experience generally have experience of dealing with customers, and generally fit better with the culture of the organization.' (Company B)

Students with work experience will potentially have a broader range of examples in their personal inventory to demonstrate the desired behaviours to employers. Surprisingly, however, employers were not particularly concerned about where graduates had obtained their part-time work experience, with all environments deemed to be able to provide adequate opportunities to develop desirable skills and behaviours:

'Shelf stacking would be important to us at short-listing stage. Shows commitment. Being employed helps to get a better rounded person. Demonstrates discipline of getting up and going to work.' (Company C)

'Any PT work experience would be deemed to be valuable.' (Company B)

These views are useful to students, who typically gain part-time employment mostly in the retail and hospitality sectors, traditionally high-volume recruiters of students. ${ }^{2}$ While employers did not explicitly specify work experience as a criterion for selection and recruitment onto their respective graduate programmes, they did emphasize the importance of part-time working in terms of helping to develop a more 'rounded individual':

'Obviously the discipline and grade of degree is important for chartered accounting recruits, but we are often looking for the "more rounded individual". The more focused upon the degree and the less work and life experience, the less likely they are to adapt to working environment.' (Company $\mathrm{C}$ )

'Always look on the CV for others things that have been done, as well as their degree, for example, involvement in Young Enterprise programmes. This gives them more strings to their bow. We do see a difference in graduates who have experience of the world of work - more grounded! They do also interview better - more to draw upon.' (Company D)

Nonetheless, discussion at the interviews regarding graduates who had previous management experience as a result of promotion in their respective part-time jobs generated a mixed response, with some employers understanding that it might be something that could be further developed; for other employers, with more structured graduate development programmes, it was not seen to add value to an application, and might even be perceived to be detrimental:

'This would be very attractive to [Company I] as someone would have seen something in their leadership abilities to put them in that position. May have received some training which [Company I] can then build upon.'

'Management responsibility wouldn't be singled out. There is a three-year training contract. Shouldn't come in thinking they can supervise because they have previously supervised. Won't be able to fast-track.' (Company C)

Similarly, there was a mixed response with regard to charitable work or volunteering. Those organizations that actively engaged with the community saw it as valuable personal criteria:

'Specifically, [Company B] wants people to be involved in the community, so candidates who have done this kind of work previously with voluntary organizations would be well-placed.'

'Also looking for voluntary activity as selection criteria for graduates. If people haven't volunteered may not get through to next stage.' (Company F) 
However, other employers perceived charitable working as merely another item on the application which added little of any significance:

'If a candidate had done voluntary activity rather than working in a bar or restaurant it would be viewed by (Company I) as 'other valuable experience'. It would probably not be seen as too beneficial to the organization.'

'Personally, volunteer work doesn't really stand out.' (Company E)

This indicates that individuals will need to consider charitable working carefully as a career development activity. The organizations used in this research sample, however, were commercial enterprises and therefore the charitable sector - which could have provided a different perspective to the value of charity/volunteering activities - was not represented.

However, the employers were generally agreed in condemning some graduate applications, not only for poor grammar and spelling but also for failing to make the most of their skills and work experience:

'In [Company B's] experience, students do not sell themselves actively enough - do not draw out their previous experience which can be very relevant. Sometimes the advice from university careers can conflict with advice that employers may give. For example, I would personally move employment experience above qualifications on a CV. Students should try to match their attributes to the skills that employers are looking for.'

'Some students can't demonstrate the impact of what they've done. Best forms seem to come from the higher end universities. Good applicants need to show how they demonstrate the competencies.' (Company F)

\section{Discussion}

The two research approaches showed that work experience is clearly important to employers, not only as a differentiator between applicants but also, for SMEs in particular, as a tool to gauge how well individuals will perform once in-post. Experience of the workplace is seemingly viewed by employers as an indicator of the graduate's readiness for employment. In addition, work experience is perceived by employers to give individuals a broader range of skills and 'wider-life' experiences, seemingly providing a greater measure of maturity than someone who has only been exposed to school and academic study. Here, the concept of a 'rounded individual' emerged from both the documentary analysis and the interviews, indicating that individuals need to expose themselves to a broad range of experiences outside the classroom. This suggests that the degree on its own is becoming less important to employers, as confirmed by Tomlinson (2007) and Yorke (2004), something which might result in more individuals pursuing alternative routes to employment to that of university study.

Experience of working in a chosen-career sector prior to entry provides what Billet and Ovens (2007) describe as a 'taster' and demonstrates commitment to the chosen vocation. Only 5 of the 24 companies graded as ' 1 ' (explicitly specifying work experience) in the documentary analysis, required work experience to be in their particular sector, however. It is therefore clear from the documentary analysis and the subsequent interviews that it is not critical how or where the work experience was gained. What is important is how that work experience can be translated and shown as relevant and useful in the context of the graduate employer. As Tymon (2011) questions, however, applicants seemingly do not make the most of their work experience, explaining its impact and practical application, which leads to frustration on the part of the employer, and results in the typical 'lack of preparedness of graduates' comment that emerged from the interviews.

Nonetheless, individuals need to exercise care in progressing in their part-time job role, since one of the SMEs viewed with suspicion those with supervisory experience, as if the individuals concerned would make higher demands on entry, or try to 'shortcut' a structured training programme. This possibly explains why one organization was graded ' 6 ' in the documentary research, by specifying a maximum work experience period to gain entry into its graduate scheme. However, smaller organizations would presumably not have the typical structured graduate development schemes that are common with large corporations.

\section{Implications for individuals and organizations}

A key aspect for students emerging from the research was the importance employers attached to customer-facing skills. Given that students typically work mostly in the retail and hospitality sectors, this should provide them with useful experience to be included in graduate applications. However, while Jackson (2013) highlights the importance of students being able to articulate fully their skills to employers, it seems that students fail to make the most of part-time work experience when applying to potential employers (Neill et al, 2004). 
Surprisingly, only one organization in the documentary analysis referred to the usefulness of charity work: the organization was based in the voluntary sector, in fact. Similarly, students undertaking charity work received mixed a mixed response in the interviews, with those with ongoing community or charitable activities welcoming it and others being more 'neutral' to its value in the graduate recruitment process. However this might simply be symptomatic of the commercial organizations contributing to this research and therefore not something that applies more widely.

The documentary analysis revealed a significant number of graduate recruiters not specifically mentioning work experience. However, they were demanding with regard to individuals being able to demonstrate traits, behaviours or 'softer skills', such as problem-solving, in the recruitment process. Raybould and Sheedy (2005) found that nearly two-thirds of available graduate vacancies were open to graduates of any discipline. This strongly suggests that employers -those included in the Raybould and Sheedy study, at any rate - were looking for the softer skills rather than degree-specific knowledge. Again, the SMEs interviewed emphasized that work experience helped to develop these transferable skills. However, employers are not particularly explicit in specifying how individuals should demonstrate the desired characteristics or behaviours, just that applicants must possess them and be able to contextualize them in relation to an employer's business.

For universities, there is a clear need to ensure students are 'employment-ready' upon graduation. Employers are looking for individuals who can demonstrate skills beyond those related to and acquired during academic studies, supported by examples that are relevant to a particular employer's business. However, as Hunt et al (2011) suggested, this requires HEIs to consider alternative approaches to delivering skills needed by employers, especially so with regard to SMEs.

Where a student does not possess work experience, the onus must fall on universities to develop the employability skills demanded by employers. There is clearly a need for HEIs not only to provide and facilitate work opportunities, but also to ensure students develop and practice appropriate skills during any work experience; and, subsequently, to help the students exploit and articulate these skills in the graduate application process. However, the concerns expressed by others regarding the ability of students to perform highly in their academic studies while at the same time accumulating the requisite work experience (see, for example, Curtis and Shani, 2002) need to be taken into consideration. Should students' part-time working be incorporated into a wider learning experience while at university, perhaps through explicit, accredited work-based learning components, embedded within academic programmes (Knight and Yorke, 2002)?

\section{Conclusions}

This study has identified the importance of work experience for graduates with regard to employability. It also signals the importance of focusing on the development of transferable/employability skills during the course of students' academic study, and how part-time working in particular can contribute to the acquisition and development of these skills and to personal profiles. At the same time, it has raised further research questions that should open up debate not only for those in universities who are responsible for managing work placements and internships but also career services with regard to information and support at the time when students will be applying for graduate positions. Moreover, it challenges educators in HE to make the most of those work experiences in the classroom, both to support and enhance student learning, and future employability; for instance, in the use of accredited work-based projects linked to their experience and critical reflection upon learning.

The study has also highlighted the needs of employers, and that individual students should be able to demonstrate possession of skills that will support a business and its development needs. Possession of the necessary skills is largely perceived by employers as something to be gained from work experience and a practical application of knowledge and understanding in a workplace setting. Nevertheless, how well individuals 'sell' the experience, making it relevant to the recruiting employer, is also of paramount importance.

In addition, this work has also shown the value of students' part-time work experience as a differentiator in the recruitment process. This should initiate a change in the way graduates perceive part-time work undertaken while studying, from being merely a source of finance to being a key driver in supporting career aspirations.

The limitations of the study lie in dealing with graduate recruitment schemes 'at a distance' through an analysis of documents. A more in-depth study might therefore yield further insights into the needs and expectations of employers with regard to work experience. Furthermore, while the sample of SMEs provided a broad coverage of industrial sectors, this could also be extended, to include, for example, those in the voluntary sector, and thus achieve a more accurate representation of UK organizations. 
JOBNAME: IHE PAGE: 9 SESS: 4 OUTPUT: Wed Jul 15 13:24:49 2015

/hling/journals/ipp/105/484638

Using part-time working to support graduate employment: employer needs and perceptions

\section{Notes}

${ }^{1}$ See http://www.top100 graduateemployers.com/; and http://www.thejobcrowd.com/top-companies-to-work-for. ${ }^{2}$ See: www.thestudentroom.co.uk/wiki/Part-Time_Work.

\section{References}

Bennett, R. (2002), 'Employers' demands for personal transferable skills in graduates: a content analysis of 1,000 job advertisements and an associated empirical study', Journal of Vocational Education and Training, Vol 54, No 4 pp 457-476.

Billet, S., and Ovens, C. (2007), 'Learning about work, working life and post-school options: guiding students reflections on paid part-time work', Journal of Education and Work, Vol 20, No 2, pp 75-90.

Boden, R., and Nedeva, M. (2010), 'Employing discourse: universities and graduate employability', Journal of Education Policy, Vol 25, No 1, pp 37-54.

Branine, M. (2008), 'Graduate recruitment and selection in the UK', Career Development International, Vol 13, No 6, pp 497-513.

Burke, L., Marks-Maran, D.J., Ooms, A., Webb, M., and Cooper, D. (2009), 'Towards a pedagogy of work-based learning: perceptions of work-based learning in foundation degrees', Journal of Vocational Education and Training, Vol 61, No 1 pp 15-33.

Burn-Callander, R. (2014), 'What the skill shortage means for UK SMEs', http://www.telegraph.co.uk/sponsored/business/ sme-home/11070446/skills-shortage.html, accessed 17 April 2015.

Cherry, M. (2015), 'Student employability and business collaboration', http://charteredabs.org/student-employabilityand-business-collaboration/, accessed 15 April 2015.

CIPD (2013), 'Apprenticeships remain poor relation to university education, say working parents', http://www.cipd.co.uk/ pressoffice/press-releases/apprenticeships-remain-poorrelation-university-education-working-parents-110313.aspx, accessed 05 May 2015.

CMI (Chartered Management Institute) (2014), 21st Century Leaders: Building Practice Into the Curriculum to Boost Employability, www.managers.org.uk/21 CLeaders, accessed 07 July 2015

Cummings Carson, L. (2013), 'Bridging the gap: internships can benefit students and employers', Public Relations Tactics, Vol 20, No 1, p 18.

Curtis, S., and Shani, N. (2002), 'The effect of taking paid employment during term-time on students' academic studies', Journal of Further and Higher Education, Vol 26, No 2, pp 129-138.

BIS (Department for Business, Innovation and Skills) (2012), Graduate Recruitment to SMEs, https://www.gov.uk/bis, accessed 02 June 2015

Ellis, D. (2014), 'Unpaid internships: work for pay, not pay for work', Telegraph Online, 20 March, http:// www.telegraph.co.uk/education/universityeducation/studentlife/10709334/Unpaid-internships-work-for-pay-never-payfor-work.html, accessed 07 July 2015.

Evans, C., Gbadamosi, G., and Richardson, M. (2014) 'Flexibility, compromise and opportunity: students' perceptions of balancing part-time work with a full-time business degree', International Journal of Management Education, Vol 12, No 2, pp 80-90.

Feldman, D.C., Bearden, W.O., and Hardesty, D.M. (2006), 'Varying the content of job advertisements: the effect of message specificity', Journal of Advertising, Vol 35, No 1, pp 123-141.

Gray, D.E. (2014), Doing Research in the Real World, Sage, London.
Harrison, S. (2004), 'Overcrowded placements hinder student learning', Nursing Standard, Vol 18, No 22, p 7.

Harvey, L. (2005), 'Embedding and integrating employability', New Directions for Institutional Research, Vol 2005, Issue 128, pp 13-28.

Heaton, N., McCracken, M., and Harrison, J. (2008), 'Graduate recruitment and development', Education + Training, Vol 50, No 4, pp 276-288.

Helyer, R., and Lee, D. (2014), 'The role of work experience in the future employability of higher education graduates', Higher Education Quarterly, Vol 68, No 3, pp 348-372.

High Fliers (2014), The Graduate Market in 2014 http://www.highfliers.co.uk/download/GMReview14.pdf, accessed 07 July 2015.

Hills, J.M., Robertson, G., Walker, R., Adey, M.A., and Nixon, I. (2003), 'Bridging the gap between degree programme curricula and employability through implementation of work related learning', Teaching in Higher Education, Vol 8, No 2 , pp 211-231.

Hunt, I., O'Brien, E., Tormey, D., Alexander, S., McQuade, E. and Hennessy, M. (2013), 'Educational programmes for future employability of graduates in SMEs', Journal of Intelligent Manufacturing, Vol 24, No 3, pp 501-510.

ICM Research (2013), 'Higher apprentices are the most employable', http://www.icmunlimited.com/media-centre/ blog/higher-apprentices-are-the-most-employable, accessed 17 April 2015.

Jackson, D. (2013), 'Student perceptions of the importance of employability skill provision in business undergraduate programs', Journal of Education for Business, Vol 88, No 5, pp 271-279.

Juznic, P., and Pymn, B. (2011) Students on placement: a comparative study', New Library World, Vol 112, No 5, pp 248-260.

Knight, P.T., and Yorke, M. (2002), 'Employability through the curriculum', Tertiary Education and Management, Vol 8, No 4, pp 261-276.

Krippendorff, K. (2013), Content Analysis: An Introduction to its Methodology, 3rd edition, Sage, London.

Martin, E., and McCabe, S. (2007), 'Part-time work and postgraduate students: developing the skills for employment', Journal of Hospitality, Leisure, Sport and Tourism Education, Vol 6, No 2, pp 29-40.

Mathews, B.P., and Redman, T. (1998), 'Managerial recruitment advertisements - just how market orientated are they?', Journal of Selection and Assessment, Vol 6, No 4, pp 240-248.

Mason, G., Williams, G., and Cranmer, S. (2009), 'Employability skills initiatives in higher education: what effects do they have on graduate labour market outcomes?', Education Economics, Vol 17, No 1, pp 1-30.

McQuaid, R.W., and Lindsay, C. (2005), 'The concept of employability', Urban Studies, Vol 42, No 2, pp 197-219.

Morrison, K. (2009), 'Higher education students in part-time work in a Chinese city', Evaluation and Research in Education, Vol 22, No 2-4, pp 121-144.

Neill, N., Mulholland, G., Ross, V., and Leckey, J. (2004), 'The influence of part-time work on student placement', Journal of Further and Higher Education, Vol 28, No 2, pp 123-137.

NUS (2010), Students in Employment \& Post Course Plans, http://www.nus.org.uk/PageFiles/4017/NUS StudentExperienceReport.pdf, pp 32-27, accessed 07 July 2015.

NUS (2009), Overstretched and Overdrawn: Student Hardship Survey, http://www.nus.org.uk/Documents/Overstretched\% 20 and\%20Overdrawn.pdf, accessed 14 July 2015.

OECD (2013), Skills Development and Training in SMEs, OECD iLibrary, http://www.oecd-ilibrary.org/industry-and-services/ skills-development-and-training-in-smes_9789264169425en, accessed 07 July 2015. 
JOBNAME: IHE PAGE: 10 SESS: 4 OUTPUT: Wed Jul 15 13:24:49 2015

/hling/journals/ipp/105/484638

Using part-time working to support graduate employment: employer needs and perceptions

Paisley, C., and Paisley, N.J. (2010), 'Developing skills via work placements in accounting: students and employer views', Accounting Forum, Vol 34, No 2, pp 89-108.

Pan, Y-J., and Lee, L-S. (2011), 'Academic performance and perceived employability of graduate students in business and management: an analysis of nationwide graduate destination survey', Procedia - Social and Behavioral Sciences, Vol 25, pp 91-103, http://www.sciencedirect.com/science/article/pii/ S1877042811023585, accessed 07 July 2015.

Paton, G. (2014), 'Four-in-ten graduate jobs reserved for student interns', Telegraph Online, 13 January, http:// www.telegraph.co.uk/education/educationnews/10566757/ Four-in-10-graduate-jobs-reserved-for-student-interns.html.

Rae, D. (2007), 'Connecting enterprise and graduate employability: challenges to the higher education, culture and curriculum?', Education + Training, Vol 49, No 8, pp 605-619.

Raybould, J., and Sheedy, V. (2005), 'Are graduates equipped with the right skills in the employability stakes?', Industrial and Commercial Training, Vol 37, No 4/5, pp 259-263.

Richardson, M., Evans, C., and Gbadamosi, G. (2009), 'Funding full-time study through part-time work', Journal of Education and Work, Vol 22, No 4, pp 319-334.

Ryan, M. (2010), 'Can you afford not to go to university?' http://news.bbc.co.uk/1/hi/education/8556307.stm, accessed 17 April 2015.

Sandelowski, M. (2010), 'What's in a name? qualitative description revisited', Research in Nursing and Health, Vol 33, No 1, pp 77-84.

Schreier, M. (2012), Qualitative Content Analysis in Practice, Sage, London.

Sfedi (2012), Graduate Recruitment to SMEs, report on behalf of the Department for Business, Innovation and Skills, https://www.gov.uk/government/uploads/system/uploads/ attachment data/file/68936/bis-13-546-graduaterecruitment-to-smes.pdf, accessed 17 April 2015.

Shafie, L.A., and Nayan, S. (2010), 'Employability awareness among Malaysian undergraduates', International Journal of Business and Management, Vol 5, No 8, pp 119-123.

Smith, K., Clegg, S., Lawrence, E., and Todd, M.J. (2007), 'The challenges of reflection: students learning from work placements', Innovations in Education and Teaching International, Vol 44, No 2, 131-141.

Stewart, J., and Knowles, V. (2000a), 'Graduate recruitment and selection: implications for $\mathrm{HE}$, graduates and small business recruiters', Career Development International, Vol 5, No 2, pp 65-80.

Stewart, J., and Knowles, V. (2000b), 'Graduate recruitment and selection practices in small businesses', Career Development International, Vol 5, No 1, pp 21-38.

Støren, L.A., and Aamodt, P.O. (2010), 'The quality of higher education and employability of graduates', Quality in Higher Education, Vol 16, No 3, pp 297-313.

Tomlinson, M. (2007), 'Graduate employability and student attitudes and orientations to the labour market', Journal of Education and Work, Vol 20, No 4, pp 285-304.

Tomlinson, M. (2008), 'The degree is not enough: students' perceptions of the role of higher education credentials for graduate work and employability', British Journal of Sociology of Education, Vol 29, No 1, pp 49-61.

Tymon, A. (2011), 'The student perspective on employability', Studies in Higher Education, Vol 38, No 6, pp 841-856.

UCAS (2011), Balancing Your Work and Study, http://www.ucas.com/how-it-all-works/starting-your-studies/ managing-money/balancing-your-work-and-studies, accessed 19 July 2011.

UEAPME (2011), Learning While Working: How Skills Development in SMEs Can Be Supported, http://www.ueapme.com/IMG/pdf/UEAPME_background_ note_learning_while_working_SME_needs_041111.pdf, accessed 02 June 2015.

Vasagar, J. (2011), 'Third of graduate jobs will go to people with work experience, poll shows', The Guardian online, 18 January 2011, http://www.theguardian.com/education/2011/ jan/18/third-graduate-jobs-work-experience, accessed 07 July 2015.

Wienclaw, R.A. (2009), Sociological Content Analysis Research Starters Sociology, http://www.academicpub.com/ map/items/29605.html, accessed 13 July 2015.

Wilton, N. (2008), 'Business graduates and management jobs: an employability match made in heaven', Journal of Education and Work, Vol 21, No 2, pp 143-158.

Wilton, N. (2011), 'Do employability skills really matter in the UK graduate labour market? The case of business and management graduates', Work, Employment and Society, Vol 25, No 1, pp 85-100.

Yorke, M. (2004), 'Employability in the undergraduate curriculum: some student perspectives', European Journal of Education, Vol 39, No 4, pp 409-427. 